\title{
Fragile Masculinity: Social Inequalities in the Narrative Frame and Discursive Construction of a Mass Shooter's Autobiography/Manifesto
}

Chrystie Myketiak

University of Brighton

\section{Contemporary Social Science}

[Pre-publication version]

Published version available here:

http://dx.doi.org/10.1080/21582041.2016.1213414

\begin{abstract}
Mass shootings, where four or more people are injured or killed, are widely constructed as a contemporary American social problem. This article uses critical discourse analysis guided by thematic analysis to examine the text written and distributed by a mass shooter in California in 2014. Analysis of the narrative frame and discursive construction shows that the author is motivated by a precarious or 'fragile' relationship to masculinity that involves positioning himself against both women and other minority ethnic men in a way that underscores multiple social inequalities. This work contributes to the social science of narrative by building on the connections between positioning theory and framing, which are applied to a text that contributes to debates in feminist linguistics and broader discussions of mass shootings. The findings contribute to feminist linguistics by demonstrating how a mass shooter uses language to rationalise his actions through a frame of hegemonic masculinity based on social inequalities, namely gender, race/ethnicity, sexuality, and social class. Finally, this work contributes to broader discussions of mass shooters by demonstrating how this mass shooter does not construct or position himself in a way that is exceptional or extraordinary but rather hinges on a fragile form of contemporary masculinity that uses violence as a way to prove self-worth, dominance, and superiority.
\end{abstract}

\section{Introduction}

On 23 May 2014, in Isla Vista, California, a young man stabbed three men to death in his apartment, shot three women at a sorority house (killing two), shot and killed one man in a deli, and then drove through the city's streets shooting and injuring several pedestrians while striking others with his car. Police found the perpetrator, Elliot Rodger, in his car, dead from a self-inflicted gunshot. In the autobiography or manifesto called My Twisted World: The Story of Elliot Rodger that he circulated on the day of the murders he alternates between referring to himself as a weak, invisible, 
good guy and a magnificent, superior god who posits that a beautiful, blonde girlfriend will provide him with recognition from others. As the text progresses, he gives up on the idea of a girlfriend, believing that women have persecuted him, and plans a 'Day of Retribution' to be enacted primarily towards women, whom he blames for rejecting him, and secondarily towards the men he believes that women prefer.

This paper uses critical discourse analysis grounded by thematic analysis to investigate framing and positioning within the text. While the shooter may have had mental health issues, as some newspaper articles have underscored (e.g., Nagourney et al. 2014; Parker 2014), he does not emphasise his mental health in the text. ${ }^{1}$ The research question in this data-driven analysis is how this mass shooter discursively constructs his narrative frame with respect to women and minority ethnic men, given that he refers to himself as "half white" (Rodger 2014: 17, 84), "half-Asian" (Rodger 2014: 17, 121), and "Eurasian" (Rodger 2014: 121). This question is addressed because women/sexuality are a key theme in the text, and how this theme intersects with race/ethnicity contributes to the understanding of social inequalities and cultural codes, particularly as they concern mass shootings and masculinity.

\section{Mass Shootings}

Mass shootings are a serious social issue in the United States, and the Federal Bureau of Investigation (FBI) reports that the number of active shootings

\footnotetext{
${ }^{1}$ While Rodger refers to appointments with psychiatrists and counselors, he glosses over his health when discussing his counselors, both men and women. He frames them in relation to dynamics of heterosexuality, race, and materialism that he uses in the text more generally. Health providers who are women are treated as potential (sexual) material goods that can improve his status. Meanwhile, health providers who are men are seen as competition for women and their perceived heterosexual success is contrasted with his failure.
} 
doubled between 2000-2006 and 2007-2013 (FBI 2013). ${ }^{2}$ Statistics on the number of mass shootings vary greatly: from a low of 64 between 2000-2013 (FBI 2013) and a high of approximately 1000 occurring between November 2012 and October 2015, as calculated by the website www.shootingtracker.com, which crowd-sourced information before joining the non-profit organisation Gun Violence Archive in 2016. While the statistics from a crowd-sourced website/non-profit organisation may appear to lack legitimacy, they are worth mentioning because broadsheet news organisations have repeatedly used them, making the statistics appear both prominent and credible to the general public, while mass shootings are constructed as newsworthy. ${ }^{3}$

The variation in the data can be attributed to different definitions of 'mass shooting'. The statistics on the lower end reflect the FBl's precise definition, which is currently defined as "three or more killings in a single incident" (FBI 2013: 9), and excludes shootings that can be attributed to gang- or drug-related violence (FBI 2013: 5). The federal explanation of a 'single incident' is dependent upon on the event occurring within a "confined and populated area" (FBI 2013: 5). 'Confined' operates as a linguistic marker that requires the caveat that incidents occurring outside, albeit in a confined space, are included (FBI 2013). The Gun Violence Archive uses more flexible criteria, of an incident in which at least four people are injured or killed, which includes the intent to kill, and the possibility that the actions are carried out over a general space. The mass shooting discussed in this article fits within the more open definition: three individuals were shot, with two killed, in one location; another was shot and killed shortly after; then more individuals were shot and injured as the

\footnotetext{
${ }^{2}$ The $\mathrm{FBI}$ considers mass shootings as a sub-type of active shootings. The definition of active shooter used by American government agencies is "an individual actively engaged in killing or attempting to kill people in a confined or populated area" (FBI 2013: 5).

3 The Guardian and The Washington Post, for example, have published multiple news stories that use this data (e.g., Ingraham 2015a, 2015b; Teague 2015; Woolf 2015).
} 
perpetrator drove through the city's streets. ${ }^{4}$ In addition to the gun violence, three people were stabbed to death and others were struck by the offender's automobile. ${ }^{5}$

While there is disparity in mass shooting definitions, demographics about shooters are consistent. Men commit the vast majority of these crimes, and findings show minimal variation: 95.8\% from 1976-2011 (Fox and DeLateur 2014), 96.2\% from 2000-2013 (FBI 2013), and 97.7\% from 1966-2015 (Bridges and Tober 2016). Although women are extremely unlikely to perpetrate mass shootings, they represent $43.4 \%$ of mass shooting victims but only $23.4 \%$ of all murder victims (Fox and Levin 2015). As well as the over-representation men as perpetrators and of women as victims in this murder subtype, there is an obstinate association of whiteness with both mass murderers and mass shooters (Lankford 2015); however, approximately $62 \%$ of American mass shooters are considered white (Fox and DeLateur 2014), while 2010 Census data indicates that $74.8 \%$ of the American population identifies as white (Humes et al. 2011). ${ }^{6}$

\section{Masculinity Discourses}

Studies of masculinity have stressed that masculinity is a social and cultural construct that is variable across space, time, and practice (e.g., Bridges 2014; Connell 1995; Connell and Messerschmidt 2011), although not all versions are valued equally

\footnotetext{
4 When www.shootingtracker.com joined the Gun Violence Archive, the Gun Violence Archive's methodology was adopted, which means that the shooter is not counted among the dead/injured. The Gun Violence Archive defines a single event as an incident occurring "at the same general time and location" (www.gunviolencearchive.org/methodology, last accessed 1 July 2016).

${ }^{5}$ Combining a mass shooting with other violence is not unusual. For example, Eric Harris and Dylan Klebold set two bombs that failed to detonate at the Columbine shootings (Kellner 2008; Tonso 2009), while Anders Breivik was successful with his bomb, which killed eight people, before shooting 69 teenagers at a youth summer camp in Norway (Seierstad 2016).

${ }^{6}$ It is not clear how Fox and DeLateur (2014) define 'white'. The US Census uses the definition of people who identify their "origins in any of the original peoples of Europe, the Middle East or North Africa" (Humes et al. 2011: 3).
} 
(Connell 1995). Hegemonic masculinity derives meaning from its relationship to both femininities and non-hegemonic masculinities, and serves and orienting function, which "require[s] all other men to position themselves in relation to it" (Connell and Messerschmidt 2005: 832). With these two elements working in tandem, hegemonic masculinity supports the dominance of men and the subordination of others, particularly women.

Although hegemonic masculinity is related to issues of privilege and oppression, it is not a binary in which people are either privileged or marginalised. Individuals have multiple identities, some of which may accord them with privilege (e.g., masculinity and whiteness) and others that may not (e.g., queerness and poverty), and not all those who benefit from inequality may feel privileged (Kimmel 2013). One reason why this may be the case is that gender can be considered "done" (West and Zimmerman 1987) or constituted in everyday life. If we consider hegemonic masculinity as comprised in practices, it can be gained or lost. This means that it is possible to reconceptualise 'attributes', which tend to be seen as fixed or inherent, as values that are demonstrated. If thought this way, masculinity is associated with: bravery, strength, dependability, emotional stability, rationality, and economic security (Coston and Kimmel 2012: 98). People can exhibit various aspects of masculinity in one interaction, or even in a conversational turn, as sociolinguists have shown (e.g., Coates 2003; Kiesling 2007). Masculinity can also be demonstrated through symbols as Stroud's (2012) work shows, which investigates the reasons that men carry concealed handguns, finding that they often do so out of fantasies of violence. For these men, the gun symbolises bravery, strength, and the ability to protect others - grounding the wearer's ideas (and ideals) of hegemonic masculinity. As well as the physical gun, Mechling (2014) discusses how 'marksmanship' was constructed by American rifle organisations as an activity for developing characteristics associated with masculinity, such as mental alertness, 
competitiveness, and physical fitness. The argument here is that masculinity can be understood as practices enacted into being that realise and constitute gender, individually and socio-culturally.

Related to hegemonic masculinity is the notion that there are a number of ways in which its 'fragility' or contestability can be exhibited in everyday life. This is heightened by what Kimmel (2013: xiii) describes as "the end of the era of men's entitlement, the era in which a young man could assume, without question, it was not only 'a man's world', but a straight man's world". Examples where this can be seen include: symbols (e.g., carrying a concealed handgun to demonstrate bravery on demand, because the value (i.e., bravery) requires a prop); consumer products (e.g., tissues marketed as "mansize" or satchels as "manbags", implying that gender-neutral products are insufficiently masculine); communicative practices (e.g., saying "no homo" after demonstrating affection or complimenting another man in order to stress heterosexuality, implying that compliments and affection are not hetero-masculine practices).

In other words, the fragility of masculinity is the sticky space of enacting masculinity within narrow confines, and the fear of being caught failing at demonstrating dominance and superiority, given that hegemonic masculinity is privileged and rewarded (Kimmel 2013). Because of the relationship between the practice and its acceptance, Messerschmidt (2011) asserts that hegemonic masculinity is proved, which is echoed by Coston and Kimmel (2012: 99) who state, "masculinity often includes a preoccupation with proving gender to others". Critical to the notion of proving masculinity is the idea that individuals' actions (e.g., the interactional level) are understood and interpreted as symbolic performances (e.g., placed within social and cultural contexts).

Theorising masculinity in a way that takes its delicacy into consideration links to 'positioning' (cf. Harré and van Lagenhove 1999), which serves as an alternative 
view to the more traditional and fixed 'role' (Harré et al. 2009). Positioning works as a metaphor on multiple levels when used to understand social and linguistic dynamics. Starting from the spatial metaphor that people occupy positions, and that these change (e.g., sitting/standing; professor/partner), at the socio-interactional level people communicate ideas about themselves (self-positioning) and attempt to place others. To understand masculinity within positioning theory emphasises how masculinity is constructed, flexible, and dependent upon the axes of time and space.

'Hegemonic masculinity' is not a fixed character type, always and everywhere the same. It is, rather, the masculinity that occupies the hegemonic position in a given pattern of gender relations, a position that is always contestable... It is the successful claim to authority, more than direct violence, that is the mark of hegemony (Connell 1995: 77).

Here Connell (1995) posits that hegemonic masculinity rests in successful claims to authority that are negotiated in social acts. Discursive research on masculinity has shown that these social practices include interaction (e.g., Andersson 2008; Cameron 1997; Myketiak 2015). While Connell (1995) states that successful declarations of 'authority' characterise hegemonic masculinity more than direct violence, violence represents the most toxic claim to dominance. When a claim to hegemonic masculinity is made through violence, a co-interlocator cannot contest it in the same way that might be possible in a conversation. This is most pronounced if the person claiming hegemonic masculinity through violence murders those who could potentially challenge a claim to authority. Murder is literally, rather than figuratively, a toxic form of silencing potential dissent to masculine claims of supremacy.

\section{Exceptionality, Masculinity, and Mass Shootings}

Mass shootings represent a specific type of extraordinary violence, and there may be a tendency to frame perpetrators as extraordinary for committing these acts. Cameron and Frazer (1987) explain this as constructing murderers as either heroes 
or monsters. The focus on framing murderers as exceptional has been critiqued by Downing (2013), who suggests that it allows society to see murders as anti-social subjects rather than as social products. Within mass shooter research, there is often a focus on what makes mass shooters 'different' or 'deviant' that emphasises potential cognitive distortions of mass shooters (e.g., Dutton et al. 2013; Knoll 2010a, 2010b; Meloy et al. 2001; Sandberg et al. 2014). This stress has the potential to absolve sociocultural discourses, perpetrators' interpretations of those discourses, as well as other salient information. For example, when connecting mental health concerns and mass shootings Metzl and Macleish (2015: 240) focus on the information that "up to $60 \%$ of perpetrators of mass shootings in the United States since 1970 displayed symptoms including acute paranoia, delusions, and depression before committing their crimes". However, if the focus is on commonalities amongst offenders, there is no aspect more significant than gender, and rape is the only crime similarly gender segregated. ${ }^{7}$ Mass shootings may be a psychological issue, but they are also a community, societal, cultural, and discursive issue - and key to understanding this multi-faceted subject is recognising that shootings are overwhelmingly perpetrated by men (Kimmel 2013).

Prioritising mental illness or cognitive distortions among mass shooters raises a number of concerns. The context leading to this emphasis must be acknowledged:

Only when white boys began to open fire in schools did psychologists and journalists rush to [a] diagnosis of mental illness. Apparently, urban black youth who open fire in their schools are being 'rational', while suburban white boys require significant psychological analysis" (Kalish and Kimmel 2010: 452).

While Kalish and Kimmel (2010) attribute this to assuming that African American youth were considered culpable for their actions, it is possible to understand this within the context of American race relations that perpetuates racist discourses that

\footnotetext{
${ }^{7}$ The FBI (2013) reports that $96.2 \%$ of mass shooters are men. The statistics for rape arrests are only slightly higher at $97.2 \%$; the next most segregated crimes are other sex offenses (excluding prostitution) at $92.3 \%$ and weapons crimes (including carrying and possessing) at $91.2 \%$ (FBI 2014).
} 
do not treat African American men as rational but, as Morgan (1999) notes, hyperphysical and violent. This evident in Fox and Levin (2001: 73-89), who have a chapter titled "The coming and goings of the young superpredators [sic]", which hinges on a dehumanising animalistic metaphor that evokes both hyperphysicality and violence, and is applied to primarily urban, poor, African American youth. While the African American shooter could be othered through a racist discourse, the 'suburban, white boy', as described by Kalish and Kimmel (2010), is universalised as 'anyone's son' (though with implied class, race and family structure bias) within the same problematic race relations. ${ }^{8}$ To envisage 'anyone's son' as someone who commits an extraordinary act of violence elicits fear; emphasising difference through cognitive distortion allows a separation based on presumed pathology. Arguably, the emphasis on cognitive distortion further stigmatises mental illnesses by linking psychological disturbance with rage and extraordinary violence, although people with mental illnesses commit just $4 \%$ of violent crimes (Fazel and Grann 2006). Furthermore, there is evidence that severe cognitive disturbances, such as schizophrenia, reduce the risk of violent behaviour (Brekke et al. 2001; Nestor 2002). Rather than focusing on offenders' cognitive disturbance to analyse the text to uncover psychological motives for the incident, the text in this analysis is approached as a 'cultural code' that connects discourse, crime, and society.

Researchers have linked mass shooters and masculinity in various ways (e.g., Consalvo 2003; Kalish and Kimmel 2010; Kellner 2008; Tonso 2009), although there is often a linking of media and cultural studies. Consalvo (2003) examines news coverage of the Columbine shooting determining that the focus is on what could be called their exceptionality: the press constructed them as subordinated 'geeks' or as 'monsters'. Kellner $(2008,2013)$ links masculinity and the media spectacle produced

\footnotetext{
${ }^{8}$ This argument is an inversion of Caputi (1989: 447), who discusses how American serial killer Ted Bundy's white, young, middle class victims were universalized as 'anyone's daughters'.
} 
by maximising casualties. Tonso (2009) suggests that some shooters borrow from sociocultural images and tropes of violent masculinities. Kennedy-Kollar and Charles (2013) use argue that the majority of mass murderers, in their sample of 28 , experienced stressors (financial, social, romantic, and/or psychological) that can be linked to hegemonic masculine ideals. What draws this body of work together is the focus on masculinity for understanding mass shootings, and what is missing is a discursive analysis of mass shooter texts.

\section{Narrative Frames}

There is a tradition within sociolinguistics that examines how people position themselves and their social worlds in narratives (e.g., de Fina and Georgakopoulou 2008; Grimshaw 2003; Thornborrow and Coates 2005). Labov's (1972) classic model for understanding narrative focuses on the structural components of narratives, and he later asserts that the most important aspects of a narrative are the 'complicating action', or explanation of what happened, followed by the resolution (Labov 1997). An alternative framework provided by Blum-Kulka (1993), drawing from Schiffrin (1987), focuses on the potential of narratives for constructing identity within a rubric that includes the story, the narrator, and the act of delivery. However, neither of these perspectives considers how positioning and framing within narratives might not be consistent with discursive construction. How people tell stories, and the ways that they situate themselves in those stories, link to their understanding of and relationship to social and cultural contexts. As de Fina and Georgakopoulou explain:

Tellers perform numerous social actions while telling a story and do rhetorical work through stories: they put forth arguments, challenge their interlocutors' views and generally attune their stories to various local, interpersonal purposes, sequentially orienting them to prior and upcoming talk. It is important to place any representations of self and any questions of story's content in the context of this type of relational and essentially discursive activity as opposed to reading them only referentially (2008: 382 ). 
The discursive approach for examining narratives proposed by de Fina and Georgakopoulou (2008) is socio-interactional and links speakers with social practices and semiotics. Recognising these 'sociocultural ways of telling' (cf. Hymes 1996) allows for understanding self-positioning and self-representations within a broader contextual framework. This approach makes it possible to emphasise the complexities between speakers' self-positioning, narrative frames and discursive activities allowing for more possibilities than the rigidity of identity alone.

Framing in discourse is generally associated with Tannen (1993) who understands it as the metamessages that occur in all interaction, spoken and written, and affects how utterances or messages are interpreted. This perspective draws on Bateson's (1972) work on play, which finds that monkeys use interactional metamessages to decode 'hostile' moves as 'playful' in appropriate circumstances. This perspective of framing is also indebted to Goffman (1974), who argues that there is a complicated and precise system with varying types of metamessages in everyday interaction. While Goffman (1974) was more focused on framing within the interaction, framing may emphasise social and cultural codes (Tannen 1993).

\section{Methodology}

This work applies feminist linguistics in its analysis of discourse in social and cultural contexts, which is an interpretative endeavour (Lincoln 1995). Discourse usually refers to the study of language above and beyond the sentence (Schiffrin 1992); however, there are two other widely used definitions, "language 'in use'”, and a "social practice in which language plays a central role" (Cameron and Panovic 2014: 3). In all cases, discourse analysts study the structure of text or talk in terms of form and function, but how this transpires depends on the operationalization of 'discourse'. The subfield of critical discourse analysis (CDA) is a method indebted to the Frankfurt 
School of critical social theory that underlines both the social and linguistic dimensions of analysing text/talk. van Dijk (2003: 352) explains it as "a type of discourse analytical research that primarily studies the way social power, abuse, dominance, and inequality are enacted, reproduced and resisted by text and talk in the social and political context." In practice this requires examining data to find covert patterns of language use that can be linked to social inequalities in their broader social contexts.

The CDA presented here is complemented by prior thematic analysis. Thematic analysis is a natural fit with CDA and can be applied to narrative study (Kohler Riessman 2005; Marshall and Rossman 2015). The thematic analysis uses a staged approach to identify prominent themes in the text, while the CDA fosters the analysis and discussion of those themes in relation to inequality and the social and cultural contexts.

My Twisted World: The Story of Elliot Rodger (MTW) is 137 pages of text, consists of approximately 107,000 words, and is divided into an introduction, followed by six sections and an epilogue. The text covers Rodger's life in spatiotemporal order, with each part dedicated to specific years of his life, although approximately 100 pages are devoted to his last ten years of life. The document can be considered an autobiography in that it chronicles his life and a manifesto in that it is ideological.

In order to critically analyse social inequality in the text, it is necessary to briefly contextualise it. Rodger completed the document in Isla Vista, California at 22 years of age. He was born in London, England to a white English father and a Malaysian mother of Chinese descent (Rodger 2014: 1). He expresses anger that his parents divorced when he was seven, which was also the age when he was introduced to his future stepmother (Rodger 2014:11). His parents were able to provide for him financially via: private school education (e.g., Rodger 2014: 2, 5, 27 , 43); vacations to see extended family in England, Malaysia, and Morocco, usually 
involving first- or business-class flights (Rodger 2014: 26, 36, 96); rent, monthly stipend, and luxury sports car, the latter he believes should attract women (Rodger 2014: 128, 129).

The process of thematic coding and analysis was iterative, and directed by two matters: first, exacting and recording the patterns of themes in the data; and second, the link between the themes and masculinity. Both high-level themes and low-level subthemes were generated, with the highest level as follows: (1) women/sex, (2) wealth/money, (3) prestige, (4) popularity/invisibility, (5) race/ethnicity, war/retribution, and (7) media consumption. The analysis and discussion focus on the intersection of two themes ( 1 and 5 ) but draw from the others. As will become evident, women and sex are collapsed together as a single category because the two are conflated in the text.

Using this text raises ethical issues, the first of which is whether the document is 'public'. Rodger wrote the text for readers and shared it with more than two-dozen people on the day of the incident (Brown 2014; Winton et al. 2014). California news station KEYT was one of the first news organisations to make the text available after reporting that they received a copy from one of Rodger's friends (Buttitta 2015). ${ }^{9}$ While the text can be considered part of the public domain, I have removed any given names, except the author's, from all extracted text in an attempt to minimise any potential harm to the individuals mentioned in it.

Some researchers might raise objections to my use of the shooter's name on the grounds that this feeds into the 'media spectacle' (Kellner 2008) or his desire for recognition, even posthumously. I acknowledge this and have attempted to use his

${ }^{9}$ Evidence that Rodger wrote the text with readers in mind includes a statement on the first page of MTW proclaiming, "[t]his is the story of how I, Elliot Rodger came to be" (Rodger 2014: 1) and in the text's penultimate paragraph he addresses readers directly with the use of a second-person pronoun: "[w]hy was I condemned to live a life of misery and worthlessness while other men are able to experience the pleasures of sex and love women? Why do things have to be this way? I ask all of you" (Rodger 2014: 137). Other news organisations, including the New York Times and the Mirror, followed; as of July 2016 the text remains available at both websites. 
name sparingly. However, complete refusal to name individuals is usually done either protectively or to change the emphasis in a narrative, as Canadian feminists have done with the 1989 mass shooting at the École Polytechnique de Montréal. ${ }^{10}$ Neither of those rationales fit here. My analysis is based on a first-person narrative that the author distributed, and it is his use of language that is key to the positioning and frame in the text. Finally, the analysis centres upon a mass shooter who attempted to legitimise the 'annihilation' (Rodger 2014: 131) and 'eradication' (Rodger 2014: 136) of women, and there is a deep schism under those circumstances by choosing not use his name and actively making this intersectional feminist study less accessible.

\section{Heterosexual success and a racial hierarchy: analysis}

Key to analysing the narrative in relation to the frame and discursive construction of the intersection of gender and race/ethnicity in this text are situating masculine 'claims of authority' that Connell (1995) asserts are part of hegemonic masculinity. One of Rodger's methods for claiming power is through the construction of a racial hierarchy in which he places his objects of desire and those whom he perceives to be his competitors. He positions himself as more deserving of heterosexual success than other minority ethnic men and he privileges white, blonde women, describing himself at one point as "obsessed with blondes" (Rodger 2014: 66). For example,

How could an inferior, ugly black boy be able to get a white girl and not me? I am beautiful, and I am half white myself. I am descended from British aristocracy. He is descended from slaves. I deserve it more. I tried not to believe his foul words [that this other man lost his virginity at a young age to a "blonde white girl"], but they were already said, and it was hard to erase them from my mind. If this is actually true, it this ugly black filth was able to have sex with a blonde white girl at the age of thirteen while l've had to suffer virginity all of my life, then this proves how ridiculous the female gender is. They would

10 Since the second anniversary of the École Polytechnique de Montréal shooting, 6 December has been recognised as the National Day of Remembrance and Action of Violence Against Women in Canada, thus formalising an emphasis on the victims. 
give themselves to this filthy scum, but they reject ME? The injustice! (Rodger 2014: 84).

His failed heterosexuality, desire for white, blonde women, and racist ideologies coalesce here. Immediately the author attempts to establish his dominance by describing the other man as 'inferior' on the basis that he is an 'ugly black boy', which is slightly modified two further times (ugly black filth, filthy scum). In each iteration of this at least one term is repeated for emphasis, 'ugly' and 'black' from the initial phrasing are recycled for the second, and in the third the noun 'filth' from the second is used as an adjective. Rodger uses figurative language, and metaphor and repetition more specifically, to make a direct link between worthlessness and Black masculinity. The grounding of the metaphor is further illustrated by the shooter's frustration at women for failing to conceptualise Black masculinity in the same way.

Though the author is 19 years old at this point in the narrative, and the man he is describing is also an adult, he uses the term 'boy'. This noun can be understood within the context of slavery and colonialism in which many African American men, and other colonised men throughout Africa and Southeast Asia, were reduced or denied masculinity through the diminutive (e.g., 'boy', 'field boy', and 'houseboy') (Leong-Salobir 2015). Even if Rodger was not conscious of implications of his word choice, three sentences later he evokes slavery outright, '[h]e is descended from slaves'. This statement stands in contrast to Rodger's claim to be a descendent of 'British aristocracy', which is also important in a colonial context. The two together are part of Rodger's racist claim to dominance. In addition to using stressing 'British' aristocracy, he marks his whiteness directly (i.e., referring to himself as half white) as a reason why he believes he should be able to attract a white woman. It is crucial to note that it is a specific social class of whiteness that he associates himself with, especially when contrasted with the man he others. Rodger believes that he is 
inherently of more worth than the man he discusses on the basis of his race and lineage, not because of his personality, behaviour, or practices.

He conflates women and sex in this same paragraph when saying that he 'deserves it more'. It is possible to read a lack of discourse cohesion here. In the case of nouns and pronouns, generally, the pronoun that follows a noun should be congruous. Instead, he writes that the other man was able to "get a white girl" and then states, "I deserve it more". This is an example of linguistic slippage where women and sex are amalgamated. To Rodger women are sex and sex is women because they serve the same function. He views women as something to be "got" or "had", and himself as entitled to both - women and (hetero)sex. Additionally, he frames women as proving men's masculinity and worth through providing sex.

Rodger privileges whiteness and blondeness in in both men and women throughout the text. The words that appear one word before 'blonde' in the document are not merely positive but erotically charged. These are most significant word collocates: beautiful, hot, tall, pretty, handsome, silky, luscious, bright, and golden. Therefore, when his co-interlocator confides that he has had sex with an attractive, blonde white woman Rodger experiences envy but attempts to position himself with strength (e.g., superiority) rather than envy (e.g., weakness). Although he is mixedrace, he emphasises being 'half white'; the association of whiteness with beauty and desire is reconfirmed throughout the text. For example, when explaining why he dyed his hair blonde at the age of nine he states, "I always envied and admired blondehaired people, they always seemed so much more beautiful" (Rodger 2014: 17). In contrast to the linking of whiteness with beauty and supremacy, which is evident in the self-positioning of his white British identity, when he prioritises his Asian identity, it is in negative terms.

I came across this Asian guy who was talking to a white girl. The sight of that filled me with rage. I always felt as if white girls thought less of me because I was half-Asian, but then I see this white girl at the party talking to a fullblooded Asian. I never had that kind of attention from a white girl! And white 
girls are the only girls I'm attracted to, especially the blondes. How could an ugly Asian attract the attention of a white girl, while a beautiful Eurasian like myself never had any attention from them? (Rodger 2014: 121; emphasis in original).

This extract shows the complexities in how he chooses to linguistically frame his Asian ethnicity. While he initially frames his mixed ethnicity as a reason that white women might not desire or recognise him, he describes himself as full of 'rage' when realising that this rejection was not based on his ethnicity. When attempting to position himself as dominant he uses the adjective 'beautiful' and switches from 'halfAsian' to 'Eurasian'. While the adjective 'beautiful' marks an obvious difference, the choice of 'Eurasian', encompasses both ethnicities while evoking British colonialism, including the exclusionary responses of mixed race people in European colonial communities provoked during imperialism (Pomfret 2009). Rodger dismisses this man, using the same adjective that he used in the previous extract (i.e., ugly), indicating a tendency to draw connotations between multiple minority ethnic groups and 'ugliness'. This is supported by his statement 'white girls are the only girls I'm attracted to, especially the blondes', which he presents as social fact. This further use of the adjective 'ugly' supports the argument that that the term is used in a racist hierarchy that diminishes the worth of individuals who are ethnically othered by the author rather than as a reference to attractiveness. Given that his racial hierarchy privileges whiteness, and a specific subtype (i.e., blondeness), above all else, his masculinity is threatened because these minority ethnic men have been desired by the women that Rodger bestows with the most social value.

Rodger's envy and hostility is not reserved for African American and Asian men who have relationships or conversations with Rodger's ideal type. He relays another experience where seeing a man he assumed to be 'Mexican' with a 'hot blonde white girl' made him angry.

When we [Rodger and his father] sat down at our table, I saw a young couple sitting down a few tables down the row. The sight of them enraged me to no 
end, especially because it was a dark-skinned Mexican guy dating a hot blonde white girl. I regarded it as a great insult to my dignity. How could an inferior Mexican guy be able to date a white blonde girl, while I was still suffering as a lonely virgin? I was ashamed to be in such an inferior position in front of my father. When I saw the two of them kissing I could barely contain my rage, and my father was there to watch it all. It was so humiliating. I wasn't the son I wanted to present to my father. I should be the one with the hot blonde girlfriend, making my father proud (Rodger 2014: 87).

In the incident that Rodger describes, he does not speak to the couple or engage with them, yet he describes himself as "barely able to contain my rage". The occurrence that causes such 'rage' and 'humiliation' for him is seeing a "dark-skinned Mexican guy dating a hot blonde white girl". Again, as with the African-American man, he positions himself as superior and the man he racially others as "inferior", using the same adjective as previously seen. In retelling this experience, he explains that being the one without the "white blonde girl" placed him in an "inferior position", which is offered as an explanation as to why this incident was an "insult to [his] dignity": the author believes that he deserves a "white blonde girl" more than a "dark-skinned Mexican guy", just as he believes that he deserves to have sex with a "blonde white girl" more than an "ugly black boy".

Reflecting upon the classic Labovian (1972) scheme for understanding narrative, Rodger provides an evaluation here. While the complicating action is seeing the couple while out with his father, the 'so what' is the emotive response he has to the encounter. The evaluation comes in the form of the emotional responses (e.g., ashamed, humiliated) but also through the use of stylistic devices, including intensifiers (e.g., great, so) and explicatives (e.g., I regarded it as a great insult to my dignity). Because Rodger understands his masculinity as liminal and weak as a result of his lack of heterosexual success he is unable to cope with seeing a man that he believes that he is racially superior to with a woman whom he finds desirable.

There are differences in these vignettes, notably in terms of the adjectives he applies to the other men, the amount of detail provided, and in the circumstances (one 
is based on a conversation he took participated in, while the other was a couple that he observed while with his father). Yet despite these differences, the use of descriptive language is similarly emotive, though applied to different subjects. The emotive adjectives were applied to the other man in the former example, while here Rodger uses them in reference to himself. In his idealised version of masculinity he should have the good (i.e., a "hot, blonde, white girlfriend") that would elicit pride from his father because he sees himself as more entitled and worthy than a "dark-skinned Mexican boy".

In these examples, he racially others the men he describes, particularly in relation to women and sex, and race/ethnicity is the central tenet he uses to underscore his envy that these men were able to obtain the type of white, blonde woman that he could not. This occurs in other places in the text where Rodger underscores the race/ethnicity of men in his discussions of heterosexual desire and failure. For example,

[My counsellor] was half Hawaiian and half Mexican, and he wasn't that good looking. How on earth could he have managed to sleep with four girls in Isla Vista, while I had been there for two years and had none? It seemed absolutely preposterous. I didn't want to see him after I found this out (Rodger 2014: 120).

While the author does not use the term "inferior" here as in other examples, the message is similar in that he is jealous, positions himself as superior, and makes ethnicity salient. He constructs himself as superior through references to the man's ethnicity and appearance, writing that it is "absolutely preposterous" that a man he constructs as lesser than is more successful with women. As noted in other examples, Rodger provides no other details about this man beyond his ethnicity and a subjective comment about his appearance. What is striking is that even for his counsellor, someone whom he knows, Rodger is unable to offer any deeper assessment of what might make a person attractive, and his masculinity is fragile enough that he does not 
want to see his counsellor again after this, which is perceived as an attack on his masculinity.

Insight into Rodger's racist hierarchy in which he believes that he is more entitled and deserving of a blonde girlfriend can be read early in the text:

Everything my father taught me was proven wrong. He raised me to be a polite, kind gentleman. In a decent world that would be ideal. But the polite, kind gentleman doesn't win in the real world. Girls don't flock to the gentleman. They flock to the alpha male. They flock to the boys who appear to have the most power and status (Rodger 2014: 28).

He privileges whiteness because that is what he believes has the most power and status. Along with that, "a hot, blonde girlfriend" works as a material good that he believes he is more entitled to than those men whom he constructs as less deserving on account of their race/ethnicity. He frames women as capable of raising men's power and authority, but also as serving the means to for men to demonstrate masculinity. He claims to have first learned this when he was seven:

Because of my father's acquisition of a new girlfriend, my little mind got the impression that my father was a man that women found attractive, as he was able to find a new girlfriend in such a short period of time after divorcing my mother. I subconsciously held him higher regard because of this. It is very interesting how this phenomenon works... that males who can easily find female mates garner more respect from their fellow men, even children" (Rodger 2014: 11).

Here Rodger provides a context for understanding his anger and rage towards minority ethnic men for dating women that he covets. He explicitly connects heterosexual success with hegemonic masculinity, seeing it as a way to command respect from others, especially men, and prove masculine entitlement. Beyond that, he also sees his father, a white British man, as successful with women, which feeds into larger social and cultural discourses about inequality, particularly as they pertain to masculinity.

Throughout the analysis Rodger has described himself as full of rage (e.g., Rodger 2014: $84,87,121)$ towards men he has ethnically othered for dating white, 
blonde women because they have upset his understanding of who is entitled to enact hegemonic masculinity. Therefore, he places the blame both on these men for having a good (i.e., access to particular women) that he desires and on women as a group because they "are incapable of having morals or thinking rationally" (Rodger 2014:136). For Rodger, women's 'rational' choice would be choosing him over these other men, because he identifies as a half-white (Rodger 2014: 17, 84, 121), "beautiful, magnificent gentleman” (Rodger: 2014: 90).

\section{Discussion and conclusions}

Both Rodger's narrative frame and discursive construction emphasise hegemonic masculinity through inequality. These play out on different levels simultaneously and often in complex ways. The instability of his masculinity is at the core of the narrative, which is first fragile then toxic. He understands masculinity as something that is proved to others, confirming Coston and Kimmel (2012), and he attaches his self-worth to how he thinks others perceive his masculinity, which is confirmed in the final sentences of the text when he writes: "I will punish everyone. And it will be beautiful. Finally, at long last, I can show the world my true worth" (Rodger 2014: 137; emphasis in original). He constructs a version of masculinity that is based on social inequality across axes of gender, race/ethnicity, social class/status, and sexuality, which demonstrates the importance of the 'claim to authority' to hegemonic masculinity (Connell 1995). This is complicated, however, by Rodger's mixed race identity. His version of masculinity derives its worth from the recognition and validation of others, which he views through a racial hierarchy of white supremacy that is based in British colonialism. He sees hegemonic masculinity as enacted through possessing the ideal girlfriend. To him, she is a beautiful blonde white woman who serves a specific function: her visibility proves his worth to others. Women in 
general, and beautiful, blonde women, more specifically, represent both his failure in and his method for claiming masculine power and authority through non-violent means.

Rodger uses language, including figurative language, to demonstrate masculine-oriented entitlement of women and to position himself as dominant. Linked to this is his rage when he believes women reject him, while other men are 'chosen', as he sees it as a statement about his value. His racial hierarchy that privileges white blonde women leads him to denigrate minority ethnic men who date women that he desires. The reasoning behind this is two fold: firstly, in Rodger's construction of masculinity, women operate as high-status material goods who exist only as objects, with the primary purpose of raising men's status. It is quite revealing that early in the text Rodger refers to his stepmother as "my father's acquisition" (Rodger 2014: 11), as this cements the idea that he believes women can be bought or purchased at will, and that they serve a symbolic function. Secondly, he believes that he is more entitled to date the women he covets (i.e., blonde, white women) because he identifies as 'half white', which he equates with prestige and power.

Throughout the text he attempts to claim authority over women and other minority ethnic women, which he eventually plans to act out through a violent "Day of Retribution". He believes that a girlfriend will provide him with recognition and status. When he is unsuccessful in 'acquiring' a girlfriend, it is not simply that his sexuality is under threat but his masculine identity is rendered invisible because he sees the social acknowledgement of heterosexuality as confirmation of masculinity. He positions himself as a 'good guy', similar to Stroud's (2012) concealed handgun carriers, but one who is victimised and persecuted by women, and uses grandiose and excessive terms to position himself as dominant, such as 'magnificent, beautiful' and 'descended from British aristocracy'. Although these two sides may appear to be in conflict they show the toxicity of his feebleness: he is caught fumbling at proving 
hegemonic masculine authority and being unable imagine it, let alone seize it, without gender, racial or class-based inequality or mass violence. When he gives up on the idea of achieving masculinity through possessing a girlfriend, turns to violence as a modality to claim masculine authority and exert dominance over both women and other men because he sees no other way to gain the power that he believes he has been denied as a result of heterosexual failure. While Kennedy-Kollar and Charles (2013) stress that "subordination and control of women are crucial aspects of the hegemonic masculinity identity" of $25 \%$ of mass murderers in their sample, and that is obviously key here, what is imperative to note is that it is not misogyny acting alone.

Analysis of the narrative frame and discursive construction of this text demonstrates that misogyny, racism, colonialism, and a heteropatriarchial discourse whereby women are commodified as sexual goods for masculine subjects operate in tandem. Furthermore, this is not an 'exceptional' discourse or an 'exceptional' man, this is a man whose perspectives are represented in the sticky spaces of hegemonic masculinity. The toxicity of his ideologies is represented in how violence becomes a way to demonstrate the worth that he feels he has been unjustly denied. The conclusions of this work demonstrate how the framing and discursive construction of this incident are based on a complex and fragile relationship to masculinity that cannot be separated from social inequalities and the desire for domination, providing insight into this specific case as well as the metamessages of a mass shooter text, especially as they relate to contemporary masculinities more generally, and how mass shootings might be understood as grounded in social and cultural discourses that are characterised by inequality. 


\section{References}

Andersson, K. (2008). Constructing young masculinity: a case study of heroic discourse on violence. Discourse \& Society 19(2): 139-161.

Bateson, G. (1972). Steps to an ecology of mind: Collected Essays in Anthropology, Psychiatry, Evolution and Epistemology. Chicago: University of Chicago Press.

Blum-Kulka, S. (1986). Shifts of cohesion and coherence in translation. In J. House \& S. Blum-Kulka (eds.) Interlingual and Intercultural Communication (pp. 1736). Tubingen: Gunter Narr.

Blum-Kulka, S. (1993). 'You gotta know how to tell a story': telling, tales, and tellers in American and Israeli narrative events at dinner. Language in Society 22(3): 361-402.

Brekke, J.S., Prindle, C., Bae, S.W., \& Long, J.D. (2001). Risks for individuals with schizophrenia who are living in the community. Psychiatry Services 52(10): 1358-1366.

Bridges, T. (2014). A very 'gay' straight? Hybrid masculinities, sexual aesthetics and the changing relationship between masculinity and homophobia. Gender \& Society 28(1): 58-82.

Bridges, T. \& Tober, T.L. (2016). Mass shootings and masculinity. In M. Stombler \& A. Jungels (eds.) Focus on Social Problems: A Contemporary Reader (pp. 507526). Oxford: Oxford University Press.

Brown, P. (2014, 28 May). California killer's parents frantically searched for son during shooting. CNN.com http://edition.cnn.com/2014/05/25/justice/santa-barbarashooter-parents/ (last accessed 1 July 2016)

Buttitta, J. (2014, 24 May). Elliot Rodger manifesto: a look inside. KEYT.com http://www.keyt.com/news/elliot-rodger-manifesto-sneak-peekinside/26162212 (last accessed 1 July 2016)

Cameron, D. (1997). Performing gender: Young men's talk and the construction of heterosexual masculinity. In S. Johnson \& U.H. Meinhof (eds.) Language and Masculinity. Oxford: Blackwell.

Cameron, D. \& Frazer, E. (1987). The Lust to Kill: A Feminist Perspective on Sexual Murder. Cambridge: Polity.

Cameron D. \& Panovic, I. (2014). Working with Written Discourse. London: Sage.

Caputi, J. (1989). The sexual politics of murder. Gender \& Society 3(4): 437-456.

Coates, J. (2003). Men Talk. Oxford: Blackwell.

Connell, R. W. (1995). Masculinities. Berkeley: University of California Press.

Connell, R. W. and Messerschmidt J. W. (2005) Hegemonic masculinity: rethinking the concept. Gender \& Society 19(6): 829--859.

Consalvo, M. (2003). The monsters next door: Media constructions of boys and masculinity. Feminist Media Studies 3(1): 27-45.

Coston, B.M. \& Kimmel, M. (2012). Seeing privilege where it isn't: Marginalized masculinities and intersectionality of privilege. Journal of Social Issues 68(1): $97-111$.

de Fina, A. \& Georgakopoulou, A. (2008). Analysing narratives as practices. Qualitative Research 8(3): 379--387.

Downing, L. (2013). The Subject of Murder: Gender, Exceptionality, and the Modern Killer. Chicago: University of Chicago Press.

Dutton, D.G., White, K.R. \& Fogarty, D. (2013). Paranoid thinking in mass shooters. Aggression and Violent Behavior 18(5): 548-553.

Fazel, D. \& Grann, M. (2006). The population impact of severe mental illness on violent crime. American Journal of Psychiatry 163(8): 1397-1403.

Federal Bureau of Investigation (FBI). (2013). A Study of Active Shooter Incidents Between 2000 and 2013. Washington, DC: US Department of Justice. 
Federal Bureau of Investigation (FBI). (2014). Table 42: Arrests by Sex, 2014. https://www.fbi.gov/about-us/cjis/ucr/crime-in-the-u.s/2014/crime-in-the-u.s.2014/tables/table-42 (accessed 1 July 2016)

Fox, J.A. \& DeLateur, M.J. (2014). Mass shootings in America: Moving beyond Newtown. Homicide Studies 18(1): 125-145.

Fox, J.A. \& Levin, J. (2001). The Will to Kill: Making Sense of Senseless Murder. London: Allyn \& Bacon.

Fox, J.A. \& Levin, J. (2015). Extreme Killing: Understanding Serial and Mass Murder (Third edition). London: Sage.

Goffman, E. (1974). Frame Analysis. New York: Harper \& Row.

Grimshaw, A. (2003). Discourse and sociology: Sociology and discourse. In D. Schiffrin, D. Tannen, H.E. Hamilton (eds.) The Handbook of Discourse Analysis (pp. 750-771). Oxford: Blackwell.

Harré, R. \& Van Lagenhove, L. (1999). Positioning Theory. Cambridge: Blackwell.

Harré, R., Moghaddam, F.M., Cairnie, T.P., Rothbart, D. \& Sabat, S.R. (2009). Recent advances in positioning theory. Theory \& Psychology 19(1): 5-31.

Humes, K.R., Jones, N.A, \& Ramirez, RR. (2011). Overview of Race and Hispanic Origin: 2010 Census Briefs. US Census Bureau. http://www.census.gov/prod/cen2010/briefs/c2010br-02.pdf (last accessed 1 July 2016).

Hymes, D. (1996). Ethnography, Linguistics, Narrative Inequality. London: Taylor and Francis.

Ingraham, C. (2015a, 1 October). Shooting in Oregon: So far in 2015, we've had 274 days and 294 mass shootings. The Washington Post. https://www.washingtonpost.com/news/wonk/wp/2015/10/01/2015-274-days294-mass-shootings-hundreds-dead/ (last accessed 1 July 2016).

Ingraham, C. (2015b, 12 October). There have been 1,001 mass shootings in America since 2013. The Washington Post. https://www.washingtonpost.com/news/wonk/wp/2015/10/12/there-have-been1001-mass-shootings-in-america-since-2013/ (last accessed 1 July 2016).

Kellner, D. (2008). Guys and Guns Amok: Domestic Terrorism and School Shootings from the Oklahoma Bombing to the Virginia Tech Massacre. Boulder: Paradigm.

Kiesling, S. (2007). Men, masculinities, and language. Language and Linguistics Compass 1(6): 653-673.

Kohler Riessman, C. (2005 [1993]). Narrative Analysis. Thousand Oaks: Sage.

Labov, W. (1972). Sociolinguistic Patterns. Philadelphia: University of Pennsylvania Press.

Labov, W. (1997). Some further steps in narrative analysis. Journal of Narrative and Life History, 7(1-4): 395-415.

Lankford, A. (2015). Race and mass murder in the United States: A social and behavioural analysis. Current Sociology (2015): 1-21.

Leong-Salobir, C. (2015). "Cookie" and "Jungle Boy": A historical sketch of the different cooks for different folks in British colonial Southeast Asia, ca. 18501960. Global Food History 1(1): 59-79.

Lincoln, Y. S. (1995). Emerging criteria for quality in qualitative and interpretive research. Qualitative inquiry 1(3): 275-289.

Kalish, R. \& Kimmel, M. (2010). Suicide by mass murder: Masculinity, aggrieved entitlement, and rampage school shootings. Health Sociology Review 19(4): 451-464.

Kennedy-Kollar, D. \& Charles, C.A.D. (2013). Hegemonic masculinity and mass murderers in the United States. Southwest Journal of Criminal Justice 8(2): 4658. 
Kimmel, M. (2013). Angry White Men: American Masculinity at the End of an Era. New York: Nation Books.

Knoll, J.L. (2010a). The "pseudocommando" mass murderer: Part I, the psychology of revenge and obliteration. Journal of the American Academy of Psychiatry and the Law Online 38(1): 87-94.

Knoll, J.L. (2010b). The "pseudocommando" mass murderer: part II, the language of revenge. Journal of the American Academy of Psychiatry and the Law Online 38(2): 263-272.

Marshall, C. \& Rossman, G.B. (2015). Designing Qualitative Research (Sixth Edition). London: Sage.

Mechling, J. (2014). Boy Scouts, the National Rifle Organisation, and the domestication of rifle shooting. American Studies 53(1): 5-25.

Meloy, J.R., Hempel, A.G., Mohandie, K., Shiva, A.A. \& Gray, B.T. (2001). Offender and offense characteristics of a nonrandom sample of adolescent mass murderers. Journal of the American Academy of Child \& Adolescent Psychiatry 40(6): 719-728.

Metzl, J.M. \& MacLeish, K.T. (2015). Mental illness, mass shootings, and the politics of American firearms. American journal of public health 105(2): 240-249.

Morgan, M. (1999). No woman no cry: Claiming African American women's place. In M. Bucholtz, A.C. Liang \& L.A. Sutton (eds.) Reinventing Identities: The Gendered Self in Discourse (pp. 27-45). Oxford: Oxford University Press.

Myketiak, C. (2015). The co-construction of cybersex narratives. Discourse \& Society 26(4): 464-479.

Nagourney, A., Cieply, M., Feuer, A. \& Lovett, I. (2014, 1 June). Before brief, deadly spree, trouble since age 8. New York Times.

http://www.nytimes.com/2014/06/02/us/elliot-rodger-killings-in-californiafollowed-years-of-withdrawal.html (last accessed 1 July 2016).

Nestor, P.G. (2002). Mental disorder and violence: personality dimensions and clinical features. American Journal of Psychiatry 159(12)1973-1978.

Parker, R. (2014, 27 June). Peter Rodger: Elliot Rodger was not evil, but he was mentally ill. Los Angeles Times. http://www.latimes.com/local/lanow/la-mepeter-rodger-son-20140627-story.html (last accessed 1 July 2016).

Pomfret, D. (2009). Raising Eurasia: Race, class, and age in French and British colonies. Comparative Studies in Society and History 51(2): 314-343.

Rodger, E. (2014). My Twisted World: The Story of Elliot Rodger. [Manifesto].

Sandberg, S., Oksanen, A., Berntzen, L.E. \& Killakoski, T. (2014). Stories in action: The cultural influences of school shootings on the terrorist attacks in Norway. Critical Studies on Terrorism 7(2): 277-296.

Schiffrin, D. (1987). Discourse Markers. Cambridge: Cambridge University Press.

Schiffrin, D. (1996). Narrative as self-portrait: sociolinguistic constructions of identity. Language in Society 25(2): 167-203.

Seierstad, A. (2016). One of Us: The Story of a Massacre and its Aftermath. London: Virago.

Stroud, A. (2012). Good guys with guns: Hegemonic masculinity and concealed handguns. Gender \& Society 26(2): 216-238.

Tannen, D. (1993). Framing in discourse. Oxford: Oxford University Press.

Teague. M. (2015, 11 October). Inglis, Florida: home to the $1000^{\text {th }}$ US mass shooting since Sandy Hook. The Guardian.

https://www.theguardian.com/world/2015/oct/11/mass-shooting-florida-1000thsandy-hook (last accessed 1 July 2016).

Tonso, K.L. (2009). Violent masculinities as tropes for school shooters: The Montreal massacre, the Columbine attack and rethinking schools. American Behavioral Scientist 52(9): 1266-1285.

Thornborrow, J. \& Coates, J. (2005). The Sociolinguistics of Narrative. Amsterdam: 
John Benjamins.

Winton, R., Xia, R. \& Lin II, R.G. (2014, 25 May). Isla Vista Shooting: Read Elliot Rodger's graphic, elaborate attack plan. Los Angeles Times.

http://www.latimes.com/local/lanow/la-me-In-isla-vista-document-20140524story.html\#page=1 (last accessed 1 July 2016).

Woolf, N. (2015, 2 October). Oregon college shooting is $994^{\text {th }}$ mass gun attack in US in three years. The Guardian. http://www.theguardian.com/usnews/2015/oct/01/obama-oregon-college-shooting-routine (last accessed 1 July 2016). 